\title{
Punishment the Easy Way
}

\section{Christopher Nathan ${ }^{1}$ D}

Accepted: 14 September 2020 / Published online: 2 October 2020

(c) The Author(s) 2020

\begin{abstract}
Some argue against coercive preventive measures on the grounds that they amount to cloaked forms of punishment. Others offer a qualified defence of such measures on the grounds that such measures have substantively different goals and purposes from punishment. Focusing on the case of civil preventive injunctions, I clear the ground and provide reasons for a third logical possibility: that coercive preventive measures are relevantly similar to punishment, but this does not itself give us a reason to oppose them. 'Punishment' has a great deal of rhetorical force, and it thereby distracts us from the justificatory work that we need to do to specify proper restrictions on the state's coercive powers. Whereas many commentators have proposed that legal theory provides grounds for challenging civil preventive orders, I argue for the opposite view. If we understand properly the function of civil preventive orders, we will endorse them at least in principle, and will come to rethink some central ideas in the grounding of the criminal justice processes.
\end{abstract}

Keywords Preventive orders · Punishment · Definition of punishment $\cdot$ Prevention

\section{Introduction}

In a move that was widely described as an innovative legal step, a UK court placed a long-term injunction on six men, prohibiting them from publicly approaching any female under the age of $18 .{ }^{1}$ The case involved a vulnerable 17-year-old girl who is under the care of Birmingham Council. The judge concluded, 'I am satisfied, so that I am sure, that the reason why they invited [the girl] into their car was for nefarious purposes.' The injunction was thus granted. The 'two-stage' order here involves creating a rule for an injunctee, in a civil court, which, if violated, is subject to criminal sanction.

\footnotetext{
1 “Family Law Week: Birmingham City Council V Sk [2016] Ewhc 310 (Fam),". For press reporting see Press Association, “Two Men Banned From Approaching Girls,” 17/112014.

Christopher Nathan

c.m.j.nathan@warwick.ac.uk

1 University of Warwick, Coventry, UK
} 
If it was possible to convince a judge, so that he was "sure" about the men's purposes, why did the council not mount a full prosecution against them? A criminal prosecution would have enabled proper punitive measures, and it would have placed the men under the more powerful control of the probationary services. The reported reason for the Council's muted ambition in charging the men is that the Council doubted a prosecution would succeed. In particular, the bar of beyond reasonable doubt in criminal courts is difficult to achieve. Injunctions, on the other hand, are granted in civil courts, where the standard of proof is merely the balance of probabilities. A full criminal prosecution may be made against the men in the future.

This case is a forceful example of what some legal scholars see as a more general trend in our criminal justice system towards 'preventive' instead of 'punitive' justice. ${ }^{2}$ It is noted that as criminalisation of preparatory acts — such as conspiracyincreases, we give powers to police to intervene earlier with the goal of stopping harmful actions from occurring. Of course, preventive and punitive justice often work in tandem. Prosecuting and punishing are good mechanisms for preventing crime. However, the Birmingham case is one in which prevention is prior to prosecution and punishment. An injunction is not meant to be punishment. It is not meant to be directly censorious, it is not a criminal charge, and it does not carry the official reprobation or implications of a full criminal record. Rather, it limits the actions of those who may act in a harmful way with the aim of preventing those harms.

The goal of prevention is extremely attractive. Crimes that would have been committed are not committed; harms that would have been inflicted are not inflicted. What could outweigh such powerful goods as the prevention of crimes and harms to innocents? The practice of prevention is also in one way superior from the perspective of the would-be criminal. One can expect that it is better for a person's mental and physical wellbeing that he is merely limited in his movements and actions under the terms of an injunction, as opposed to the serious hardship implied by a period of incarceration following the commission of a crime. It is also, debatably, better for a person's own moral wellbeing that she commits fewer wrongs.

In light of this, what, if anything, could be said against such practices of prevention? One of the eventual subjects of the Birmingham injunction informed the judge that he would agree to abide by a long-term injunction without making legal representations against it. Then, after the judge announced that he intended to name the subject of the injunction publicly, the man changed his mind and fought, unsuccessfully, against it in the courts. In contrast with the Council, the local police force opposed the public naming of the man. The weight placed by the parties upon the publicity of the order indicates something significant about the way it is generally construed. The people who are subject to it will expect a high degree of censure and stigmatisation from their local community and thereby have strong reason to avoid it. For some commentators, this element of censure, in combination with the limitations on liberty the injunction imposes, means that it should be understood

\footnotetext{
${ }^{2}$ Andrew Ashworth and Lucia Zedner, Preventive Justice (Oxford: Oxford University Press, 2014).
} 
as something that is relevantly similar to, or actually constitutes, a punishment. ${ }^{3}$ Furthermore, continues the objection, punishing a person rightly carries a series of strong procedural safeguards, not least the requirement that guilt is proved beyond reasonable doubt.

This paper focuses on objections to preventive orders that include the claim that such orders are punitive. The paper shows that this claim is correct-coercive preventive orders are indeed punitive-but that it does not necessarily undermine their legitimacy. Section 2 sets out the landscape of the debate. Section 3 establishes the prima facie credibility of two-stage orders by rebutting objections to them that do not make appeal to their criminalisation-like aspects. Section 4 argues that such orders may be construed as forms of punishment, and section 5 argues that this is not sufficient to reject them as legitimate. Section 6 concludes by defending the value of a more expansive conception of punishment.

\section{Three Options}

A substantial part of the debate about coercive preventive orders revolves around three mutually inconsistent claims:

1. Justifiability of the civil preventive practice Coercive preventive measures of some given type, $P$, can legitimately be implemented without strong process restrictions, such as the requirement of proof of grounds beyond reasonable doubt at trial.

2. Punitive nature of the practice Coercive preventive measures type $P$ are effectively (for the purposes of normative evaluation) a form of punishment.

3. Proper limits on punishment Punishment should only be administered following processes that involve the availability of strong process restrictions, such as the requirement of proof of grounds beyond reasonable doubt.

For each coercive preventive measure, we must reject at least one of these three claims. In the case of civil preventive orders, there is a series of arguments that pushes us to deny (1), especially in cases involving sexual offences. Such arguments hold that because of their punitive nature, such orders can only be granted legitimately if a criminal-like procedure is followed. The 'strong process restriction' that is present in criminal trials but absent in preventive orders that I will focus on-for reason of space-in the examples in this paper is the requirement that convictions are made with a presumption of innocence until a person is proven guilty beyond reasonable doubt. To be sure, I will touch on the other high standards that criminal procedures are required to meet that may not be met by preventive orders, such as

\footnotetext{
3 Notably, ibid. See also Heidi Mork Lomell, "Punishing the Uncommitted Crime: Prevention, Pre-Emption, Precaution and the Transformation of Criminal Law," ed. Barbara Hudson and Synnove Ugelvik, Justice and Security in the 21st Century: Risks, rights and the rule of law (Routledge); Andrew Von Hirsch and AP Simester, Crimes, Harms, Wrongs: On the Principles of Criminalisation (Hart 2011).
} 
clarity of the rules, the absence of retrospective application, and the principle of equality of application. ${ }^{4}$

Some writers are inclined instead to deny (2) with respect to certain civil preventive orders. In the UK context, we can see the preventive rationale of Sexual Offence Prevention Orders expressly in recent Home Office Guidelines:

the fundamental purpose of a SOPO is to protect the public from serious sexual harm...To obtain an order, the police will need to establish that there is a reasonable cause to believe that an order is necessary to protect the public, or individual members of the public, from serious sexual harm. ${ }^{5}$

Similarly, for many kinds of coercive police work that aims to prevent harm, it will be common to deny that they are punitive. For instance, in defending the use of kettling at protests or the denial of bail to a person facing trial who is believed to be violent, it is claimed that the practice is aimed only at preventing harm.

However, I argue in this paper for the third possibility: that we can accept (1) and (2) but reject (3). In the next section, I cast doubt on direct objections to (1). That is, I suggest we can legitimately impose civil preventive orders without the full restrictions typically provided in criminal law. In the following section I give a defence of (2), showing that preventive measures can be functionally and normatively equivalent to punishment. In this case, we will have to reject the universal strong restrictions on the imposition of legitimate punishment that (3) asserts. I conclude by arguing that this is less galling than it initially appears, in the light of the preceding discussion and our existing security practices.

\section{Coercive Preventive Measures of the Given Type Can Legitimately be Implemented}

In this section, I rebut some objections to preventive orders tout court that do not make appeal to their status as punitive. The arguments I discuss here rest, respectively, on autonomy, equality before the law, legislative will, and delegation of powers.

\footnotetext{
4 A fuller list is provided by Andrew Ashworth and Lucia Zedner,: “(a) the presumption of innocence [until proven guilty beyond reasonable doubt]; (b) the right to be informed of the nature of an accusation; (c) the right to have adequate facilities for defence; (d) the right to legal assistance; (e) the right to confront witnesses; (f) the right to the free assistance of an interpreter; (g) the privilege against selfincrimination and right of silence; (h) the principle of arms; (i) the right of confidential access to a lawyer; (j) the right not to be subjected to retroactive criminal laws; (k) the right to have criminal laws of the necessary quality, ie certainty of definition; and; (1) the right not to be subjected to a higher penalty than was applicable at the time of the conduct." Andrew Ashworth and Lucia Zedner, "Preventive Orders: A Problem of Undercriminalization," ed. R.A. Duff and others, The Boundaries of the Criminal Law (Oxford University Press, 2010), 83. I focus in this paper on (a), and also discuss a development of (k) and (1), as well as (h).

5 Home Office, "Guidance on Part Two of the Sexual Offences Act 2003," (2012), 43. It should be noted that SOPOs were replaced with Sexual Risk Orders and Sexual Harm Prevention Orders in 2015.
} 
What we may call the autonomy objection holds that coercive preventive laws improperly treat people as prima facie harmful. This objection appeals to freedom or autonomy or the ability to choose otherwise. By limiting a person's freedom to act before he commits a crime, we treat him as a thing to be controlled instead of respecting him as a person who can choose. As one author urges, in the context of inchoate crimes, "criminalisation of preparatory acts denies people the opportunity to change their mind. By intervening at a preparatory state, the opportunity to abandon is blocked." ${ }^{6}$ Up until the commission of a wrong, it is possible that he will change his mind, and by intervening at an earlier stage, restricting his ability to commit the wrong, we prevent this opportunity for the exercise of his moral powers. ${ }^{7}$

In general, the autonomy objection will not yield an in-principle ground for rejecting civil preventive orders. It will at most provide one value among competing others that speaks against the introduction of preventive orders. There may be value in permitting people the chance to do the wrong thing. However, it would be extreme to allow that consideration to rule out preventive measures tout court. Similarly, the bystander should not stand by and watch the gunman kill the victim when she could intervene at little cost to herself or others just so that the gunman can have the chance to do the wrong thing. ${ }^{8}$ The value of a 'window of moral opportunity' does not extend so far that we always desire its expansion. It does not, for example, warrant reverse situationist crime-prevention, i.e., situationist crime-commission. ${ }^{9}$ Furthermore, if ones accepts that states can legitimately enact programmes that prevent temptation on a small scale, then it seems difficult to offer a principled reason why states cannot intervene aggressively where it is likely that a crime will be committed.

Is there a natural default position regarding the degree of wrong that people must be free to do in order to count as autonomous? It is possible that there is, but it is unlikely that it occurs naturally.

The personal criminal law objection complains about the existence of different laws for different people that civil preventive orders create. This appeal to what one paper describes as 'legal apartheid' draws our attention to the way in which civil preventive orders propose one rule for some and another for the rest. ${ }^{10}$ Having been enjoined not to enter a certain city, use its public transport system, or associate with

\footnotetext{
${ }^{6}$ Lomell, "Punishing the Uncommitted Crime: Prevention, Pre-Emption, Precaution and the Transformation of Criminal Law," 96.

7 This objection can be routed via the view that such orders are punitive, or it can run without that claim. On the present, non-punishment version, the objection is that we should not force people to do the right thing. On the punishment version, the objection is that one should not punish except where a person has had a strong opportunity to decide to do the right thing.

8 Thanks to Kimberley Brownlee for suggesting this way of putting the point.

9 Andrew Von Hirsch, David Garland, and Alison Wakefield, Ethical and Social Perspectives on Situational Crime Prevention (Hart Publishing 2000).

10 Peter Squires and Dawn Stephen, "Pre-Crime and Precautionary Criminalisation," Criminal Justice Matters 81, no. 1 (2010), 28.
} 
certain people, one faces a different criminal landscape to other citizens. Is this not an offence to the value of equality before the law ${ }^{11}$

In a trivial sense, every legal system has different rules for different people. Driving laws do not apply to non-drivers, and laws apply in different ways to non-domiciled residents than they do to citizens. More broadly, equality before the law does not entail equal effect upon all by each law. In another sense, the application of a civil preventive order is not properly conceptualised as the creation of a personal criminal law but as the consistent use of criminal law.

Suppose that person A acts in such a way that she becomes bound by a preventive order. If the rules of application are consistently followed, then, if person B acts in the same way, person B will face a similar injunction. In this sense, there is room for equality before the law within a regime of preventive orders. In order to succeed, the personal criminal law objection must say why civil preventive orders constitute an objectionable case of different laws for different people. Objectionable cases of different laws for different people involve arbitrary or oppressive distinctions between people. Civil preventive orders do not obviously appeal to arbitrary or oppressive distinctions between people; they track culpable dangerousness, which is prima facie rational. Compare this to literal legal apartheid. One could appeal to some other argument to make the case that the difference in the case of civil prevention orders is arbitrary or oppressive. By appealing to some grounds for the objection to civil orders, one renders the appeal to a personal criminal law a spare wheel. For its success, the objection depends on an account of what makes preventive orders objectionable. $^{12}$

To be sure, there is also a pragmatic objection to preventive orders that appeals to equality before the law. It may be argued that high procedural standards can be expected to have the effect that greater scrutiny upon the workings of the criminal justice system. Further, given the existing inequalities in enforcement and effect of that system, we should be wary of any argument that would seek to lower those standards. This argument may be a sensible pragmatic response to existing injustices. However, while we might seek to respond to those injustices by placing general restrictions upon the way that the law is enforced, the goal should be to move towards a system in which the law is enforced justly. ${ }^{13}$

\footnotetext{
11 Peter Ramsay mounts the objection in the following terms, relating to the UK's regime of Anti-Social Behaviour Orders (ASBOs): "Rather than formal equality, the premise of the discretion to impose an ASBO is that an individual's rights as a citizen are relative to an administrative assessment of her fulfilment of a prior positive duty - the duty to "respect our neighbours' right to live free from harassment and distress". Peter Ramsay, "What is Anti-Social Behaviour," Criminal Law Review no. Nov (2004), 923.

12 It might be argued that preventive orders introduce an unacceptable form of inequality because they demand differential treatment of people who have not done anything that is prohibited by the criminal law. This objection is unconvincing by itself: states are inevitably involved in differential treatment of people in many contexts outside of the criminal justice system. A stronger version of this objection adds that states should not carry out the differential treatment of punishment, where those receiving such treatment have not carried out acts that are prohibited by the criminal law. I address this issue in sections 5 and 6.

13 Thanks to an anonymous reviewer for pressing me on the issue of equality before the law.
} 
The democracy objection asserts that civil preventive orders provide a way of bypassing the will of the legislature. ${ }^{14}$ On this view, they are introduced in a way that does not respect previous expressions of how the criminal law should function and, in particular, involves inappropriate power by the judiciary over legislative bodies. Ashworth and Zedner argue, for instance, that although begging has not been imprisonable since a 1982 Act of Parliament expressly rendered it a merely civil matter, it suddenly now is an imprisonable offence through a civil order in the form of an Anti-Social Behaviour Order (ASBO). Such an imprisonment would be ordered by a judge via a civil order. Ashworth and Zedner argue that this is an undemocratic state of affairs in which the judiciary can overrule a decision that Parliament made in 1982.

Understood as a principled objection to the two-stage structure of preventive orders, this is not a forceful argument. A current legislative body can legitimately overrule a previous one, certainly on matters of bread-and-butter criminal law, and the ASBO legislation can be taken as such. We might reinterpret the objection as an argument from political sneakiness: the criminalization of begging has been worked past the electorate without proper debate. This position has sway, but an objection to the process by which a piece of legislation is introduced is not an objection to the content of the legislation itself. Notoriously, not every aspect or implication of legislation is debated: perhaps the oversight is particularly egregious in this case, but the case remains to be made, and other civil preventive legislation has received closer scrutiny, including the regime that is replacing the Anti-Social Behaviour Order. The conclusion that we should have better democratic public discourse on our criminal justice reforms does not, by itself, imply the exact direction that those reforms should take.

The delegation of powers objection focuses on the way that civil preventive orders permit the decision to criminalise the otherwise inherently innocent actions of some particular person to be made by the judiciary and not the legislature. On ASBOs in particular, Peter Ramsay writes:

...whatever its procedural designation, the substantive power [in the ASBO is] a power of unelected judges, responding to the initiative of local authority officials, to limit the basic civil rights of individual citizens on the basis of a discretionary evaluation of those citizens' disposition towards each other's feelings of security. Such a power is on its face inconsistent with the rule of general laws that has characterised the civilization known as representative democracy. The ASBO should not be reformed-it should be repealed. ${ }^{15}$

The objection holds that in order to criminalise any aspect of X's behaviour, one must have proper democratic limitations on that process. Therefore, there should be proper democratic limitations on the process of civil injunction-imposition, such as consultative and legislative, and not merely judicial, processes. Thus, one ought to

\footnotetext{
14 This argument is adduced in Ashworth and Zedner, "Preventive Orders: A Problem of Undercriminalization"; Ashworth and Zedner, Preventive Justice.

15 Peter Ramsay, "Substantively Uncivilized Asbos," Criminal Law Review no. 10 (2010), 763.
} 
have the opportunity to contest the restrictions one faces, but the current structure does not permit this. In short, since a civil preventive order is relevantly similar to having some of one's behaviour criminalised, it ought to be implemented only in the same kind of way that criminalisation generally is implemented, that is, through legislative and not merely judicial processes.

In reply, this delegation of powers is not clearly different from other liberty-limiting delegations of power to the executive, such as enforced purchase orders that facilitate large public construction projects, or indeed the judiciary, such as the demand of specific performance of a contract, a power that the judiciary possess, though uses with caution. These and many more are cases of the state acting coercively without the full process of a criminal court. For what it is worth, there has not been a successful constitutional challenge along the lines Ashworth and Zedner propose to any of the various civil preventive order regimes. Ramsay's own objection to the ASBO focuses on the feelings of insecurity that are created by perceived antisocial behaviour, and the detrimental effects of a law that permits criminal enforcement of the eccentricities of people's subjective states. If that caveat is dropped, we see, instead, a smaller departure from existing security practices.

In this section, I have discussed arguments that object to civil preventive orders as a whole and that do so without appeal to their punishment-like features. ${ }^{16}$ Those arguments face serious problems. I conclude, based on this survey of prominent objections, that we should be sceptical of sweeping objections to civil preventive order, and that if we can establish evidence of their efficacy, there is a prima facie case in favour using them. ${ }^{17}$

\section{Coercive Preventive Measures as a Form of Punishment}

Some argue directly from the claim that civil preventive orders are punitive to the conclusion that strong restrictions should be placed upon their implementation. That is to say, using the argumentative schema provided in Section 2, some defend premises (2) and (3) as a way of concluding that we should reject (1). Andrew Ashworth and Lucia Zedner argue:

civil preventive orders are in reality so close to criminal offences (certainly in view of the possible consequences) that the subject ought to have access to the

\footnotetext{
16 This is not to rule out objections to the particular way that a regime for an order is framed. For example, it may be the case that the definition of 'anti-social behaviour' within the ASBO is faulty. See Andrew Cornford, "Criminalising Anti-Social Behaviour," Criminal Law and Philosophy 6, no. 1 (2012, 1-19).

17 Briefly, consider one further move. The power differential argument provides pragmatic reasons why civil preventive orders shouldn't be granted-emphasising the imbalance of power between the state and the offender-thus giving a more empirically limited scope to support for (1). Such an argument is also consistent with what I argue here. The power differential applies to all kinds of state coercion: tax policy, regulation, use of informants, and indeed punishment itself. There does not seem to be an a priori reason to think that this consideration carves out in principle all civil preventive orders.
} 
'criminal' procedural rights at the first stage of the two-step process when the terms of the prohibitions are set. ${ }^{18}$

Similarly, Simester and von Hirsch argue that where orders are wide, such as a prohibition on entering the geographical space that includes the injunctee's home,

the substance of the order, which is driven by retrospective considerations, can be comparable in onerousness to a criminal punishment. At least where the order involves a substantial curtailment of liberty, it seems to us that the civil methods of proof required for issuance of the order... are inadequate. ${ }^{19}$

That is to say, the imposition of preventive injunctions, and not merely judgments concerning their contravention, ought to be subject to the strictures of criminal, rather than civil, legal process. The consequences of the civil order in this area are so similar to those of punishment, that the order amounts to a way for authorities to circumvent normal checks on the imposition of punishment for criminal transgressions. This argument depends on a direct appeal to the punitive nature of preventive orders. I discuss some more subtle versions of this line of reasoning later in this paper. For now, note that there are two parts: first, that two-stage orders are relevantly like punishment, and secondly, that this provides an objection to them. In this section, I defend the first part of the argument; in the next section, I will deny the second.

Preventive measures do indeed often look like punishments. They can single out individuals for coercion in ways that seriously set back their interests and encourage public stigma in a way that will foreseeably be seen and taken as censorious. In concert with the critics just quoted, I propose that those receiving civil preventive orders are often not deceived when they perceive the order as a species of punishment. ${ }^{20}$

\subsection{The Justification View}

Against that claim, it might be argued that the purpose of the practice of preventive orders is ostensibly not punitive. The goal, purportedly, is only to prevent harm from occurring. Thus, some urge that coercive preventive legal measures are normatively distinct from punitive measures because the two differ in their goals or justifications;

\footnotetext{
18 Ashworth and Zedner, Preventive Justice, 89. Elsewhere in the text, they write: "pre-trial detention, immigration detention, and civil preventive orders are all coercive preventive measures that lie on, or close to, the boundaries of punitive measures". Ibid., 21.

19 Von Hirsch and Simester, Crimes, Harms, Wrongs: On the Principles of Criminalisation, 218.

20 I appeal only to a broad definition of punishment as imposing some sort of hard treatment, in a way that creates censure. Other possible elements of the concept-including the goal or function of the hard treatment, and the supposition that punishment is necessarily imposed upon those who are believed to be guilty - will be discussed in the ensuing text. In accepting that the extension of punishment is expanded beyond its conventional boundaries, it is unlikely, of course, that civil preventive orders will be the only practice that should, but typically does not, carry the label 'punishment'. For an overview of such cases, with a different resolution to the one that is put forward here, see Karol Lucken, "You Say Regulation, I Say Punishment: The Semantics and Attributes of Punitive Activity," Critical Criminology 21, no. 2 (2013, 193-210).
} 
that punishment is properly administered in accordance with desert; and that practices of punishment aim at desert. Practices that seek to prevent harm, on the other hand, do not have built into their targets any idea of deservingness. ${ }^{21}$ Independent of culpability, they aim only at mitigating or removing a danger. As Lord Hope says in Clingham: "the purpose of the procedure is to impose a prohibition, not a penalty". ${ }^{22}$ Similarly, for the ASBO, the goal is preventive:

... the criteria for granting an ASBO are whether or not it is needed to prevent future exposure of others to the disrespectful attitude of the defendant. It is the future relationship between the defendant and other people that renders the defendant liable. ${ }^{23}$

According to this point of view, unlike a criminal offence, which would specify mens rea, the grounds for the civil preventive orders refer only to the protection of people from harm. Evidence of the injunctee's state of mind may form part of the evidence for his or her dangerousness, but the focus of the practice is fully upon whether or not a harm is likely to occur and whether a civil order is likely to prevent it, and not at all upon whether or how far the defendant would be morally responsible for that harm. Since the goal is not punishment, on this view, different principles apply. As with self-defence, the prevention of harm carries different and weaker restrictions.

In this spirit, Kimberly Ferzan writes:

Normatively, prevention and punishment are not the same sorts of acts. When the government punishes, it aims to give the defender what he deserves, and the liberty deprivation and stigma the offender suffers are constitutive of that punishment. Prevention, on the other hand, does not have this structure. The goal is to stop the crime from occurring and the liberty deprivation is associated with that goal. ${ }^{24}$

Prevention is thus subject to different proportionality constraints than punishment. ${ }^{25}$ On this view, punishment ought to be distributed, at least pro tanto, according to deservingness. What proportionality constraints do preventive practices face? On

\footnotetext{
21 Thanks to Alec Walen for pressing the importance of this argument.

22 Clingham v. Kensington and Chelsea Royal London Borough Council, 2002 U.K.H.L. 39 (2002), para 68.

23 Ramsay, "What is Anti-Social Behaviour", 916.

24 Kimberly Kessler Ferzan, "Preventive Justice and the Presumption of Innocence," Criminal Law and Philosophy 8, no. 2 (2014, 521). Similarly, where preventive orders are applied, "the intent here is not to stigmatize. The State's goal is not to mark out someone as a potential criminal but rather to engage in acts that prompt (or force) a change of mind." Kimberly Kessler Ferzan, "Beyond Crime and Commitment: Justifying Liberty Deprivations of the Dangerous and Responsible," Minnesota Law Review 96, (2011, 183-184). See also Alec Walen, "A Unified Theory of Detention, With Application to Preventive Detention for Suspected Terrorists," Md. L. Rev. 70, (2010, 871).

25 Some authors in the literature on criminalisation and punishment use 'proportionality' to mean exclusively 'proportionality to desert'. This is confusing. Treatment of a person could be proportional to many different things, and the word 'proportionate' by itself picks out none of them. C.f., for example Lawrence Alexander, "The Doomsday Machine: Proportionality, Punishment and Prevention," The Monist 63, no. 2 (1980, 199-227); Ashworth and Zedner, Preventive Justice.
} 
Ferzan's view, prevention is comparable to self-defence. If a person makes herself into a threat, then she has thereby made herself liable to harmful measures that would stop the effects of the threat. ${ }^{26}$ The extent of harm to which she is liable is proportional to factors such as (i) what is necessary to avert the threat, and (ii) the extent of the harm to be prevented. Notably, the extent of harm to which she is liable is not (as it is in the case of punishment) proportional to her degree of moral deservingness. In protecting oneself or another against an innocent threat, one infringes upon a right, perhaps justifiably, given whatever other values are at stake. The culpable threat, on the other hand, by virtue of her culpability, has waived the right against being harmed. In defending oneself against her, one does not infringe her rights at all, so long as one does not harm the threat excessively in defending oneself. ${ }^{27}$ In just the same way that the culpable aggressor waives a right against being harmed, those who threaten harms to other citizens thereby waive rights against the liberty deprivations that would prevent them from inflicting those harms. On this view, one cannot import the standards of punishment into preventive justice. Prevention and punishment are distinct. Civil preventive orders, as measures that are explicitly part of the practice of prevention, are not punitive.

This position presupposes a certain form of theory of punishment: one that is both retributivist and does not incorporate self-defence principles into its foundation. If one views the practice of punishment itself as an essentially preventive endeavour, ${ }^{28}$ then an effort to distinguish preventive from punitive practices will not wash. A similar point applies if one sees the justification of punishment as rooted in the principles that guide cases of self-defence: punishment would thereby not be distinct from the liability principles that guide self-defence. ${ }^{29} \mathrm{We}$ assume, for now, a retributivist position.

\subsection{Punishment and Expression}

We are considering the position that prevention and punishment are distinct, and that civil preventive orders, as measures that are explicitly part of the practice of prevention, are not punitive. Crucially, this position depends on the idea that we can

\footnotetext{
26 “...the defendant cannot claim, as a matter of substantive due process, that his liberty rights are being violated when he is the one who has effectively forfeited those rights." Ferzan, "Beyond Crime and Commitment: Justifying Liberty Deprivations of the Dangerous and Responsible", 162-163.

${ }^{27}$ Ashworth and Zedner put the point in the following way: "where the rationale is desert, the punishment must censure the subject in a way and to an extent that respects his or her responsible agency, and the role of prevention is to supply underlying deterrence where the choice or quantum of the sanction should be governed by proportionality considerations. Where prevention is the rationale its logic applies without respect for whether the subject is a responsible agent or not, since the purpose is to obtain the optimal preventive outcome." Ashworth and Zedner, Preventive Justice, 19. The difference between Ferzan, on one hand, and Ashworth and Zedner on the other, seems to be that the latter are prepared to impute a punitive rationale in cases where the former sees only a preventive one.

${ }^{28}$ Nicola Lacey, State Punishment (Routledge 2012); John Braithwaite and Philip Pettit, Not Just Deserts: A Republican Theory of Criminal Justice (Oxford: Clarendon 1992).

${ }^{29}$ Victor Tadros, The Ends of Harm: The Moral Foundations of Criminal Law (Oxford University Press 2011).
} 
distinguish state institutions or practices by different possible intentions or reasons that lie behind them. Now, it is possible for the proper designation of a practice to be different from what is normally understood as its ostensible purpose. In general, errors in designation are possible, and these include errors in self-designation. The question is, how seriously should we take the way that practices of preventive orders describe themselves? I suggest we ought to apply a heavy dose of scepticism. Some in the literature on preventive detention have already noted that long term preventive detention has many of the trappings of punishment, and is difficult to distinguish it in a principled way. ${ }^{30}$ Simester and von Hirsch urge that "one effect of the [two-stage prevention order] can be...to inflict something as onerous as a penalty". 31 The point expands, I suggest, to preventive orders, even where the hard treatment that such orders carry is significantly less than that imposed by lengthy preventive detention.

Like language, the contents of the expression in punishment are determined by factors that go beyond the will of the communicator. No matter how strong an effort of internal will is on the part of a communicator to say A, if she will knowingly and reliably be understood across the population to be saying B, then, I suggest, she says B. An act of imposing hard treatment fits within a network of such acts. As with a capable user of language, those who impose punishment skilfully understand in advance which acts of imposition of hard treatment will be understood as censorious, how censorious they will be considered to be, and what they will be considered to be censuring. ${ }^{32}$ The contents of the censorious element of punishment can differ from the intentions of the punishing authority, just as meaning can differ from the intentions of an author.

There are many examples of the way that the meaning of practices or acts can be appropriately determined outside of the intentions of their instigators. Consider, for example, Rae Langton's argument that pornography is a speech act that subordinates women. ${ }^{33}$ That argument does not depend upon the intentions of the pornographers. If pornography has silencing effects upon women, then the act of creating or distributing pornography is an act of silencing. As Langton says, "What we do, and what we aim to do, are not always the same." 34 Here is another, extreme example involving offence. Suppose I wear a swastika in a Jewish area with the intention of emphasising the ancient Sanskrit roots of that symbol, perhaps as a misguided attempt to begin a reclamation of the symbol, or to make an overwrought point about the nature of symbols in general. My efforts will be misjudged. I will be seen as offensive or worse. Suppose that my judgment is in one way intact: I correctly predict the responses to my actions, but I continue nonetheless on the grounds that I believe that

\footnotetext{
${ }^{30}$ Richard L. Lippke, "No Easy Way Out: Dangerous Offenders and Preventive Detention," Law and Philosophy 27, no. 4 (2008, 383-414).

31 A. P Simester and Andrew Von Hirsch, "Regulating Offensive Conduct Through Two-Step Prohibitions," in Incivilities: Regulating Offensive Behaviour, ed. A. P. Simester and Andrew Von Hirsch, (Oxford; Portland, OR: Hart, 2006), 178. For a sociology of the experience of ASBOs, see Peter Squires and Dawn Stephen, Rougher Justice (Routledge 2013).

32 I do not mean to commit to a communicative theory of punishment by making this point. It is one thing to examine the workings of the concept; it is another to argue that justified applications of the concept involve special appeal at certain points to certain of its elements.

33 Rae Langton, "Speech Acts and Unspeakable Acts," Philosophy \& Public Affairs (1993, 293-330).

34 Ibid., 301.
} 
my point is one that is worth making, even in the face of initial misunderstanding. Can I be taken seriously if I argue that the people who object to my wearing of the symbol are confused, since they are acting in ignorance of the symbol's Sanskrit roots and do not pay due regard to my intentions, which I am keen to express to any who care to listen? Of course not. I am communicating something offensive, even if I genuinely, if foolishly, do not intend this.

Externalism about meaning holds that it is possible for two individuals to have identical mental content but different meaning, so that meaning is not reducible to the intentions of the speaker. ${ }^{35}$ That position is widely, if not universally, held. Nonetheless, one need not commit to a full-blooded externalism in order to accept the argument I put forward here. I am committing only to externalism about institutional meaning, and externalism about institutional meaning is yet more plausible than externalism about individual meaning. This is because the intention in the institutional case is so nebulous, and the best interpretation of it depends so clearly in part on what the community understands the practice to be. In the individual case we can investigate, at least in principle, the mental contents of the speaker. In the institutional case, it is not clear whether the mental contents of, for example, the trial judge are relevant at all to understanding the censure in punishment. ${ }^{36}$ Different judges can impose the same sentences for the same acts but with different intentions. If the relevant intention lies in the goal, function, best justification, or telos of the institution, then one would expect that the community's interpretation of such things is partly (if defeasibly) determinative of them.

I have so far been parsing the sort of reason behind a coercive state act that is relevant to its denotion as punishment as an 'intention'. We might instead focus on possible justifications. Consider a schema put forward by Alec Walen, in distinguishing 'acts' from 'actions':

An action is an act performed for a particular set of reasons. An act is an action understood by abstracting from the reason for which it is performed.... An act is permissible if a successful justification for it can be given. An action corresponding to a permissible act may or may not be permissible, depending on whether the subjective reasons on which the agent acts make the action impermissible... [T]aking acts as basic allows us to distinguish factors that would make it impermissible for any agent to perform the act in question, no matter what her reasons for doing so, from the intentions and reasons for action that might also serve as wrong-making factors."37

\footnotetext{
35 Hilary Putnam, "The Meaning of "Meaning,", Philosophical Papers 2, (1975). Putnam famously draws the implication that "meanings just 'aint in the head." Ibid., 277. Analogously, the censorious social meaning of an act of deprivation carried out by the state can be expected to lie beyond the goal or ostensible justification of that act.

${ }^{36}$ Adam J. Kolber, "Unintentional Punishment," Legal Theory 18, no. 01 (2012, 1-29).

${ }^{37}$ Alec Walen, "Eliminative Killing and the Targeting of Noncombatants Comments on Seth Lazar's Sparing Civilians," Law and Philosophy 37, no. 3 (2018, 317-318).
} 
With this distinction in mind, it might be objected that states can apply two-stage orders permissibly if there is a justification for them that does not also appeal to the grounds for strong criminal procedure. Cases in which they are applied by judges with the goal of imposing censure remain impermissible, even if the act of imposing an order is permissible, in the sense that there is an available justification, such as that of prevention. Suppose an actor says and intends, "what I am doing is not meant to be punishment; it is merely a way of preventing you from carrying out a dangerous act.' The person on the receiving end may reply 'this seems censorious.' That feeling is relevant, but it is not by itself sufficient to define the act as punitive. Rather, we can seek to show that there $i s$ a justification for preventive acts that does not include their censure, and that these acts are justified, since 'acts' don't include the intentions. Further, continues the objection, whether any given such action of prevention (noting that 'actions' include the motivating reasons) is justified depends on whether or not it is carried out with reference to the good available justification.

In reply, the denotion of an action depends not just on the goal of those acting. Suppose I intend to engage in mild banter but say something offensive. My action is partly determined by the effect that I have had and not just by my misjudged reasons. Similarly, states can have a preventive goal that will reliably and widely be perceived as punitive; it is not a sufficient defence on the part of the state's act that the reasons behind the act are purely preventive. It would be necessary to also explain why those receiving the orders are in some way mistaken. The relevant reasons that are attached to an action should be drawn from a wider pool than merely the function or the goal of the actor. Censure can exist without a censorious goal. Focusing on acts and abstracting from reasons for action, it is possible for the act to be censorious, and a justification for it will need to justify the censure. A justification that only refers to the preventive element of the act will not justify it. A justification would need to include an account of why the experience of censure should be discounted. Could it be sufficient that the experience is not intended or is not part of the justification that it should be discounted? It is hard to make the case if the censure is foreseen. Perhaps foreseen but unintended consequences of an action face a lesser justificatory burden, but it would be extreme to argue that they face no justificatory burden.

What could be the conditions under which punishment occurs, even where it is not intended as punishment (or as hard treatment or as censure), and where it is not best justified in the normal retributive punishment-type ways (as application of desert or the expression of disapprobation)? I propose the following: 
Punishment includes cases in which hard treatment is applied that is reliably considered by the community as a whole to be censorious. ${ }^{38}$

The Birmingham case described at the outset of this paper provides a useful illustration. One of those against whom the order was made was found to have been mistakenly placed on the list. A year later, the Council successfully applied to have him removed from the order. The reason the matter was so grave was that wrongfully placing a person on such an order involves wrongfully designating him as a sexual abuser, thereby mistakenly creating the public stigmatisation that goes with punishment. A similar account of punishment is recently put forward by Geeraets. ${ }^{39}$ This view appeals to how the imposition of hard treatment could be 'reasonably interpreted.' I aspire here only to offer a sufficient condition for punishment and not a complete analysis. The possibility is open that some cases that are not reliably considered by the community to be censorious are still punishment—perhaps because, following Geeraets, the 'reasonable interpretation' of the action differs from the community's assessment.

By 'reliably' in the proposed condition I am referring to a reference class that includes the range of individuals across a population. If a person is known to be especially sensitive to tax assessments and experiences strong disapprobation when required to repay some of his income, then we need not say that that is a punishment, since his interpretation of the tax assessment is out of kilter with the norm. On the other hand, if people across the range of the population reliably experience and view some certain kind of fine as censorious, then it does fall within the category of punishment.

The case also provides a useful example of the distinction between censure and stigmatisation. The former refers to what is expressed by the act of punishment; the latter is a common public response to censure. It is possible for the latter to be absent, or to exist in only a subset of the community, as when preventive orders or even prison sentences are celebrated. While it seems definitional of punishment, the expectation of stigmatisation is indicative that the application of some given hard treatment will be reliably experienced as censorious, and thereby constitute punishment. $^{40}$

\footnotetext{
38 There are three parties involved: the agent administering a treatment, the agent receiving the treatment, and the members of the surrounding community. My suggestion is that we analyse the meaning of the treatment in the way that we analyse the meaning of words. Just as speaker cannot exercise control of meaning through pure efforts of will-the meaning will depend also on the ways that the words interact with the practices of the listener and the others who take part in the practice-so also is it not the case that an agent administering hard treatment has control, through their motives, reasons, or intentions, of the possible censorious meaning of their actions. That meaning, too, depends on the way that it interacts with the practices of the individual upon whom it is administered, and the interpretations of the surrounding community.

39 Vincent Geeraets, “Two Mistakes About the Concept of Punishment," Criminal Justice Ethics 37, no. 1 (2018, 21-35).

${ }^{40}$ For further development of the distinction between stigma and censure, see Katerina Hadjimatheou, "Criminal Labelling, Publicity, and Punishment," Law and Philosophy 35, no. 6 (2016, 567-593).
} 


\subsection{Process}

Establishing that the content of the expression behind preventive orders is not determined by the justification or function of the practice is not sufficient to show that they are properly taken to be censorious. Perhaps there is something about their content that means that they will not reliably be taken to be censorious, or with small changes in the way that they are carried out, then such experiences of censure could be avoided. Furthermore, perhaps the community ought not to understand certain practices as censorious, and so cases that fall under the heading of punishment in that sense should not so fall.

In this spirit, it may be argued that the censure necessary for punishment is not present in civil preventive orders because the standard of proof is lower in civil cases. Thus, some suggest that the civil order is only expressing a claim on the balance of probabilities, not a direct claim of guilt. ${ }^{41}$ Since there is no expression of full confidence in guilt, a civil procedure lacks strong criminal censure, disbarring the measure from qualifying as punitive.

However, the argument threatens to undermine reasons in favour of the 'beyond reasonable doubt' standard in the first place. Were we to lower the criminal standard to 'balance of probabilities,' then convictions would, on this argument, express the judgment that the person had committed the crime with certainty to that lower degree. Would we say that in that case that punishment is not being applied, and that we do not have reason to increase the standard? Surely what seems objectionable about the new lower standard regime is that we sense punishment is being administered too readily, but on the position we are considering here, punishment isn't being administered at all. In this case, we must allow that whatever censure is necessary for punishment can occur within a process that has a lesser standard of proof than 'beyond reasonable doubt,' and it seems arbitrary to exclude the civil standard from that category. ${ }^{42}$ It is in any case common for the process of imposing a civil order to provide certainty beyond what is procedurally necessary. For example, in the Birmingham case described in section 2, the judge stated that he was "sure" of the activities and intentions of the injunctee. This is one way in which punitive censure may enter into a civil procedure. ${ }^{43}$

\subsection{Substance}

Instead of focusing on the process, some argue that preventive orders are not punishment by focusing on their substance, considering the kinds of deprivation imposed by civil preventive orders, and urging that their deprivations are qualitatively

\footnotetext{
${ }^{41}$ Liz Campbell, "Criminal Labels, the European Convention on Human Rights and the Presumption of Innocence,” The Modern Law Review 76, no. 4 (2013, 681-707).

42 Indeed, the 'beyond reasonable doubt' standard has its own particular history Alec Walen, "Proof Beyond a Reasonable Doubt: A Balanced Retributive Account," La. L. Rev. 76, (2015, 355).

43 Furthermore, as a matter of fact, only a very small proportion of sentences are applied following a full trial. It is far more common for the accused to plead guilty, in the U.S., as a result of a plea bargain.
} 
different from punitive ones. In the context of discussing preventive detention, Stuckenberg argues that pre-trial and preventive detention may be legitimate so long as they do not "take on a penal character." 44 He states that treatment of a "nonpenal character' must be something to which the innocent also "may justly be subjected," though the nature of this character is not explained. ${ }^{45}$ Similarly, in the case of ASBOs, Liz Campbell argues that "the absence of hard treatment in the form of punishment per se implies that a 'clear and convincing' standard of proof would suffice." ${ }^{46}$ In contrast to Stuckenberg, she also provides a way to fill in the details:

Such state labelling of the individual through ASBOs does not equate to criminal punishment, either in terms of the substance of the label or the possible consequences-no hard treatment is involved, and the declaration does not denote a criminal conviction. Moreover, the agent of the state may not be declaring guilt as to one particular suspected act. ${ }^{47}$

Regarding hard treatment, it seems clear that some form of deprivation of liberty is involved in the imposition of preventive orders and injunctions. That a criminal conviction is absent should not distract us: it must be possible for punishment to occur without such process. Whether such punishment is just or legitimate is a different issue to whether it is punishment. Regarding specificity, it is possible to express censure and impose deprivation in response to a pattern of behaviour a person has carried out, and that this is a punitive matter. Indeed, one of the lessons of expressive theories of punishment is that we see part of the function of punishment as an engagement with the character and dispositions of the individual, rather than merely any particular act. An ASBO preventing the loud playing of music, and an injunction preventing contact with girls, each expresses clearly a judgment about the person on its receiving end. ${ }^{48}$ It may be objected that the substance is different here: what is expressed is a judgment about the person, whereas criminal law is set up so that it makes judgments about acts. ${ }^{49}$ It is unclear, however, that penal sentences are understood this way, and indeed the endorsement of a communicative structure to punishment indicates that the person committing a crime should reflect on her character. ${ }^{50}$ Furthermore, it is conceptually possible to punish a person for a future act or

\footnotetext{
44 Carl-Friedrich Stuckenberg, "Who is Presumed Innocent of What By Whom," Criminal Law and Philosophy 8, no. 2 (2014, 301-316).

45 Stuckenberg adds that compensation ought to be given where such deprivations are applied to those who are ultimately acquitted. Compensation for wrongful preventive detention is not mentioned.

46 Campbell, "Criminal Labels, the European Convention on Human Rights and the Presumption of Innocence", 706.

47 Ibid., 703.

48 Some might that preventive orders are not actual hard treatment, only, conditional hard treatment. The possibility of imprisonment occurs only on future conduct. However, prison sentences have that structure too, and prisons impose hard treatment. Prisons only physically coerce those punished if they make an attempt to escape or do not cooperate with the prison regime. Perhaps an order against doing something that you do not and would never wish to do and from which you would not benefit is not punitive. But an order against entering the geographical area that contains your house and family is punitive.

49 Thanks to Alec Walen for suggesting this objection.

50 Antony Duff, Punishment, Communication, and Community (Oxford University Press, USA 2001).
} 
for some aspect of his character, and that, again, is one natural way to interpret the preventive order.

We might in principle imagine ways of making preventive orders different to prison sentences, so that the two are taken to involve different kinds of expression, and that the former would thereby lose their censorious character. It is difficult to imagine ways of doing this that do not involve substantially offsetting the disadvantage that is imposed by the setback of a preventive order. ${ }^{51}$ For instance, a large cash payment as compensation for the hardship of the preventive order might have the effect of distinguishing the order from mainstream penal instruments. ${ }^{52}$ The likely unpopularity of such a policy, however, is both evidence that the orders really are taken as properly involving censure, and also a threat to their purpose as distinguishing preventive orders as non-punitive. Of course, the policy would be independently problematic, in the light of the incentives that it would create.

\section{Limiting Punishment}

I have urged so far that, despite being properly understood as falling under the umbrella of punishment (Section 4), there is some reason to support the existence of civil preventive orders, or at least, not to oppose them in themselves (Section 3). I also hinted, in Section 4, at arguments that run from the punitiveness of civil preventive orders to their illegitimacy. The purpose of this section is to urge that even on the understanding that such orders are punitive, we do not have a decisive objection to them just on those grounds.

I will proceed by explicating and confronting two types of objection to preventive orders, both grounded in their punitive nature. The first is that the orders are necessarily applied without regard to the appropriate standard of proof and other criminal procedures. The second is that preventive orders are necessarily applied with a proportionality standard that is appropriate for security or defence, whereas a proportionality standard that references desert would be appropriate. ${ }^{53}$

\subsection{Criminal Justice Procedural Standards}

The first objection asserts that civil preventive orders are inappropriate, where they are punitive, because they are punishments that are administered in the absence of proper procedure, and that punishment can only be applied with stringent procedures, such as evidence of proof beyond reasonable doubt that the behaviour that gave rise to the punishment was committed.

\footnotetext{
51 Lippke, "No Easy Way Out: Dangerous Offenders and Preventive Detention".

52 Michael Louis Corrado, "Punishment and the Wild Beast of Prey: The Problem of Preventive Detention," J. Crim. L. \& Criminology 86, (1995, 778).

53 Despite considering the two clearest objections, it remains open, of course, that there is another such objection that I do not consider here.
} 
Why must such standards apply to legitimate punishment? They are so embedded in popular modern thinking about punishment that it is sometimes taken as obvious that they apply. ${ }^{54}$ Asked to provide a paradigmatic case of injustice, many will offer an example of a person who has been wrongfully convicted and punished, and implicitly, will thereby endorse the principle that punishment can only be applied with rigorous epistemic standards.

I will explore this idea through the idea of the presumption of innocence. In short, the problem is that the presumption of innocence can be met without the strong standards that are required by strict criminal procedure. ${ }^{55}$ There is a growing body of argument that holds presuming innocence is empty if it is understood in a purely formal way. First, crimes can be defined in broad ways so as to create a lower standard of proof. A crime that contains elements $\mathrm{ABC}$ may be replaced with a crime that contains only elements $\mathrm{AB}$, thereby creating a state of affairs similar to one in which an individual can be charged for ABC without the need to prove C. ${ }^{56}$ Second, and relatedly, the form 'individuals should be presumed innocent' does not by itself tell us of what kind of act individuals should be presumed innocent. One can reductively rewrite rules that make no mention of presumptions into rules that invoke presumptions. For instance, an exam system could be described as presuming failure until proof of passing. That we find this illocution odd suggests that if the presumption of innocence adds anything, it is not a restriction on the form of our rules. ${ }^{57}$

So, if the presumption of innocence is to mean something, it must be a substantive norm, not a procedural one. This insight cuts the presumption free from (i) pure criminal procedure as it is carried out in courts, and (ii) the standard 'beyond reasonable doubt' in particular. We may thereby honour this core tenet of proper criminal

\footnotetext{
54 E.g., Bruce M Landesman, "Scheid's Dilemma," Criminal Justice Ethics 30, no. 1 (2011, 104), asserting that the punitive element of preventive detention renders them problematic, taking them "well beyond what is appropriate for a truly liberal society that respects liberty and the rule of law.'.

55 There are also some other, weaker arguments in existence that run via the punitive nature of preventive orders. One such view asserts that such orders amount to punishment for a possible future crime, and adds Christopher Slobogin's contention (made in the context of a discussion of preventive detention) that 'the concept of "punishment" for some future act is incoherent'. (Christopher Slobogin, "Jurisprudence of Dangerousness, a," Nw. UL Rev. 98, (2003, 12).) However, the actus reus of the relevant crime can (and likely will) not say 'will perform X', but may say 'has characteristics A, B, and C, where those characteristics mean that it is likely that the person will perform $X$ '. There is nothing conceptually incoherent about that; in order to criticise such a rule, one would need to reach beyond bare concepts. For development and defence of this view, see Douglas Husak, "Preventive Detention as Punishment," ed. Andrew Ashworth, Lucia Zedner, and Patrick Tomlin, Prevention and the Limits of the Criminal Law (Oxford University Press 2013).

56 Barbara D Underwood, "The Thumb on the Scales of Justice: Burdens of Persuasion in Criminal Cases," The Yale Law Journal 86, no. 7 (1977, 1299-1348); Victor Tadros and Stephen Tierney, "The Presumption of Innocence and the Human Rights Act," The Modern Law Review 67, no. 3 (2004, 402434).

57 Stuckenberg, "Who is Presumed Innocent of What By Whom". See also Edna Ullman-Margalit's conceptualisation of presumptions: "if there is no commitment to some value according to which one type... of errors is judged as preferable to the other, then talk of presumption in this area is inappropriate." Edna Ullman-Margalit, “On Presumption," The Journal of Philosophy 80, no. 3 (1983, 160). This supports the claim I am making here. If a presumption is meaningful it presupposes preferable types of error, and 'preferable error' is a substantive notion, not a formal one.
} 
procedure - that is, the proper procedure that is attached to punitive acts-without, of necessity, applying the 'beyond reasonable doubt standard.'

Although it may be something from which we recoil, a version of this idea is already implicit in the writings of several of the authors I have been discussing in this paper. In the context of control orders, Campbell writes:

control orders involve a determination of responsibility. Accordingly, the presumption of innocence requires us to revisit the requisite standard of proof in this instance, given that person is being depicted as a terrorist without a criminal trial and on the balance of probabilities. Rather, proof ought to be established beyond reasonable doubt, or at the very least to a 'clear and convincing' degree, before such orders may be imposed. ${ }^{58}$

On this view, because there is a determination of responsibility, the imposition of a deprivation is somewhat more like full punishment. Because it is more like full punishment, the epistemic standard limiting its application should be higher. It shifts up from the balance of probabilities to a clear and convincing standard. Campbell does not explain why it should not shift further, into the beyond reasonable doubt standard. However, we may suppose that the reasoning is that while the control order has several of the features of punishment, it does not have all of them; it is merely quasipunitive, and thereby should have a procedure closer to the standard for punishment. It would seem that there is only a matter of semantic tidiness between what Campbell argues here and what I am arguing for in this section: the difference is Campbell's reluctance to describe the control order as a case of punishment.

Other, more pragmatic, considerations may be advanced for the claim that high standards accompany all instances of legitimate state punishment. It might be urged that punitive acts are in fact stably understood by many well-functioning legal systems as legitimately imposed only where high standards of process are applied, such as the 'beyond reasonable doubt' standard. On this view, there is good reason not to change this norm because it functions effectively.

We do, however, seek more justification from our norms than apparent downstream efficacy. The same reasoning that brings us to see preventive orders as a form of punishment may also lead us to see many other actions by states as forms of punishment. The challenge is to explain whether any particular type of punishment may only ever be imposed with criminal court -like procedures. There are many activities by the state that (i) impose deprivations and (ii) are reliably considered by the community to be censorious. That is, if the way of understanding state punishment that I am urging here is correct, then there is probably much more of it than we normally think. Censure can be experienced and perceived in a variety of contexts of state action outside judicial declarations in criminal trials. Aside from the preventive order, consider the normal workings of the 'workfare' or 'means-tested' elements of a welfare system. In hearing that he is to have payments cut because he has not made adequate efforts to find work, it may be difficult for a citizen to understand the

\footnotetext{
58 Campbell, "Criminal Labels, the European Convention on Human Rights and the Presumption of Innocence", 704.
} 
message as anything other than an announcement that he has acted in a way that he should not have acted. ${ }^{59}$ Consider also many police actions. Law enforcement officers have many tools short of arrest: they might order that citizens vacate an area because they are being a nuisance or seek to obtain intelligence from those involved in minor offences, in lieu of investigating the latter. ${ }^{60}$ Actions by social services can also have this flavour. Even within the prison, where punishment paradigmatically occurs, there are further actions that should be considered under the same heading as state punishments: an inmate violates some rule, so that inmate is placed in a more depriving cell or has diminished visiting rights. Despite efforts at neutrality, it is hard for a modern state to function without expressions, through deprivations, that certain people should not have done what they did.

A number of authors criticise the 'beyond reasonable doubt' standard on the grounds that it wrongly gives excess protection to those who are guilty. Such views take account of the interests of those who may be harmed following an incorrect acquittal, as well as the interests of those who will be harmed following a wrongful conviction. ${ }^{61}$ The argument that I make here is a complement to such arguments, though it neither depends upon nor entails them. I am urging that censorious state hard treatment is commonly carried out outside of the institution of punishment, in, for example, everyday policing or in the distribution of welfare and housing benefits. Some may be inclined to respond that this revelation thereby undermines those practices. However, I would reply that many - though not all-such practices are sufficiently widespread and apparently unobjectionable that we should also respond by finding that there is a problem in explaining why the addition of censure to some state hard treatment should qualify that treatment for extremely restrictive procedures. This is especially the case where the widespread perception of censure is a conventional matter that results from the public stigma that hard treatment creates.

\subsection{Proportionate Prevention}

On the schema put forward by Ferzan, if preventive orders are often forms of punishment, then the degree of deprivation imposed by preventive orders should be matched, at least in part, to what the injunctee deserves. Of course, Ferzan is not opposing the existence of such orders tout court. She defends them on the grounds that they are a distinct practice that can be given an altogether different rationale, justified in terms of responding to people who are threats. The proportionality objection, nonetheless, complains that preventive orders may, given their punitive character, only legitimately be implemented with the proportionality constraints that

\footnotetext{
59 Such a point is offered sometimes as a reason for unconditional benefits: Guy Standing, Beyond the New Paternalism: Basic Security as Equality (Verso 2002).

${ }^{60}$ Diarmaid M Harkin, "The Police and Punishment: Understanding the Pains of Policing," Theoretical Criminology 19, no. 1 (2015, 43-58). See also my "Principles of policing and principles of punishment," Legal Theory 22.3-4 (2016): 181-204.

61 Larry Laudan, Truth, Error, and Criminal Law: An Essay in Legal Epistemology (Cambridge University Press 2006); Daniel Epps, "The Consequences of Error in Criminal Justice," Harv. L. Rev. 128, (2014, 1065). For a recent overview see Federico Picinali, "Can the Reasonable Doubt Standard be Justified? A Reconstructed Dialogue,” Canadian Journal of Law \& Jurisprudence 31, no. 2 (2018, 365-402).
} 
apply to punishment, not to prevention. Several commentators object that civil preventive orders are often disproportionate, and they make this argument, once again, with reference to the punishment-like nature of the orders. For instance:

As punishments (which is how they are perceived), ASBOs are liable to be disproportionately harsh, and are not subject to the proportionality constraints that should apply to punishments. ${ }^{62}$

According to this argument, ASBOs yield, in effect, disproportionate punishments, since a punitive procedure would impose deprivations in accordance with and to the extent only of moral desert, whereas a preventive procedure is limited only by what is likely to avoid the harm, and the latter is less constrained. A related argument is put forward by Antony Duff:

Some kinds of exclusion can be justified as punishments: temporary exclusion from a shopping mall could be an appropriate sentence for a shop-lifter, and temporary exclusion from football matches an appropriate sentence for a football hooligan. Such punishments must be justified as proportionate responses to the offender's past wrongs, however, whereas ASBOs have a purely preventive rationale. Apart from the fact that this removes a principled constraint on their possible harshness, we should object that, like other preventive or incapacitative measures, they fail to treat those subjected to them as responsible agents. ${ }^{63}$

The objection appears to be that, while the punitive rationale involves treating the offender as responsive to reasons and there are limits that come from this requirement, the preventive rationale lacks such constraints. ${ }^{64}$

Some commit to the straightforward view that the hard treatment of punishment should be in proportion always and only the independent desert of the offender. On this view, one can easily distinguish the practice of punishment from practices of preventing harms, which involve forward-looking considerations of possible acts in the future. Though it has defenders, ${ }^{65}$ such a pure retributivism is not popular and faces serious objections, including those concerning why only the particular crime under consideration should form the desert base, and why only the state should carry out the punishments. ${ }^{66}$

\footnotetext{
${ }_{62}$ Simester and Von Hirsch, "Regulating Offensive Conduct Through Two-Step Prohibitions,", 81.

${ }^{63}$ Antony Duff, "Perversions and Subversions of Criminal Law," in The Boundaries of the Criminal Law, (Oxford University Press, 2010), 100.

${ }^{64}$ From the text it may alternatively be understood that the relevant limits carried by a punitive standard of proportionality derive from other factors than the imperative to treat those subjected to punishments as responsible agents.

${ }^{65}$ A forceful defence of this type of view is Michael S Moore, Placing Blame: A Theory of the Criminal Law (Oxford University Press, USA, 2010).

${ }^{66}$ Victor Tadros, The Ends of Harm: The Moral Foundations of Criminal Law (Oxford University Press, 2011).
} 
The more complex (and mainstream) versions of retributivism incorporate considerations of prevention into their proportionality considerations. ${ }^{67}$ For example, one might take the view that censorious hard treatment should be imposed insofar as it has a preventive effect, but that it can only be imposed upon those who deserve such treatment. In such an approach, there is a deontological constraint on the extent of just punishment: people should not be punished more than they deserve, and they can be punished up to that limit where it has good effects, such as deterrence. Preventive orders, then, according to the accompanying version of the proportionality objection, can have the effect of over-punishing, since they apply punitive measures without direct consideration of what offenders are due.

Now, if desert has this basic force, then people can deserve treatment outside of actions that make them liable to criminal prosecution. The challenge for this version of the objection is to explain why the relevant kind of deservingness cannot arise with regard to preventive orders. It is not beyond the principles that govern preventive practices to appeal outside of simple consequentialist considerations, too, and to hold that some, by their actions, can make themselves liable to greater preventive interference. A practical question arises, concerning how far existing practices around two-stage orders track this concern. For example, in the Birmingham case described at the outset of this paper, it may be that the 'nefariousness' of the purposes of men establishes the relevant desert-base, or it may be that the surrounding rules require insufficient attention to agential responsibility. Either way, the objection provides at most an objection to particularities of existing practices, routed through a specific type of theory of punishment.

It is doubtful, then, that the very definition of punishment can carry so much weight as guide us away from preventive two stage orders: if the former can appeal to considerations of desert, or the value of ensuring that offenders are treated as responsible agents, then so can the latter. Indeed, those appealing to the model of self-defence will, of course, draw on proportionality and necessity constraints. ${ }^{68}$ The preventive rationale also can appeal to limits, including the value of treating the offender as responsive to reasons or responding to desert.

\section{Conclusion: Scoping Punishment}

I defend civil preventive orders against principled objections because such orders are not the radical departure that some propose. In particular, in Section 3, I rejected arguments from autonomy, personal criminal law, and democratic expression. Additionally, in the bulk of the paper, I also rejected arguments against civil preventive orders that rest on their punitive nature. Their punitive nature is not a radical

\footnotetext{
${ }^{67}$ Larry Alexander, Kimberly Kessler Ferzan, and Stephen J Morse, Crime and Culpability: A Theory of Criminal Law (Cambridge University Press 2009). Duff, Punishment, Communication, and Community. Andrew Von Hirsch and Andrew Ashworth, Proportionate Sentencing: Exploring the Principles, vol. 17 (Oxford University Press Oxford, 2005).

68 C.f. Alexander, "The Doomsday Machine: Proportionality, Punishment and Prevention”.
} 
departure because states are already engaged in coercive, punishment-like measures outside of criminal courts, in, for example, the normal functioning of the welfare system, the police force, and the prison system. A superior account of the limits on two-step criminalization will spring from this more realistic account of our normative universe. It is common in discussing civil preventive orders either to argue, implausibly, that such orders are not, in effect, punitive, or to argue, unsatisfyingly, that they should cease because of their punishment-like features. This way of setting up the debate encourages us to put more normative weight on the term 'punishment' than it can rightly bear.

Discussion of punishment and the criminal justice system has traditionally focused on its coercive and depriving aspects, asking, 'How could it be justified deliberately to make a person worse off?' More recently, mainstream focus has incorporated and turned towards another element: punishment expresses censure. Criminalisation of an act carries moral condemnation. ${ }^{69}$ This shift gives rise to an oddity. Rather than concern about whether strict procedural standards for imposing hardship are met, one becomes compelled towards a defence of strict procedural standards in the case of something as comparatively soft as a mere expression of disapproval. Focusing on the hard treatment of punishment makes it easier to see why strict procedures should be applied, but harder to distinguish the practice from other coercive state practices, like taxation, that do not aim to punish. Focusing on the expressive element of punishment makes it easier to distinguish punishment as a distinct category but leaves us in the odd position of defending high procedural standards just in virtue of the added presence of official disapproval.

That is one part of a diagnosis of the way the concept of punishment works. Here is another. We describe as 'punishment' only a subset of the category, and we do so because we know what we mean. 'State-imposed punishment with the strong process restrictions that attach to court procedures' is sometimes what we mean by punishment. However, in discussions about why punishment is justified, we quickly drop the 'strong process restrictions' from the definition, because that is among the things that we are seeking to justify, explain, account for, and guide.

An implication of my argument is that the state can legitimately punish without going through the full procedure that we would normally expect. This is troubling. It is only a part of a response to say that the extension of punishment is more widespread than we normally think and that punishment with lesser procedure is thereby more common than we normally think. Some will respond to those realisations by demanding that punishment with inadequate procedure is eliminated. It is legitimate to ask what it is about punishment that requires stringent procedures, and it is possible that the answer will involve criteria that are not possessed by all cases of punishment.

If not being appropriately designated as 'punishment,' what does mark out some state action as appropriately restricted by strict court procedures such as proof beyond reasonable doubt? Answering that question is beyond the scope of this

${ }^{69}$ Joel Feinberg, "The Expressive Function of Punishment," ed. Michael H. Tonry, Why Punish? How Much?: A Reader on Punishment (Oxford University Press, 2011). 
paper. Let me nonetheless indicate some direction. In cases in which there is no way of policing the targets with reasonable resources, we may hold that preventive orders can be justified, if effective, even where they will be stigmatising upon the subject. For example, perhaps prosecutions would be bound to fail and would in any case be carried out too late, whereas preventive orders provide a higher chance of successfully preventing a serious harm about which there is convincing intelligence. ${ }^{70}$ Those are cases where the state is not meant to be responding to people's desert. The moral culpability of the person is not a trigger in deciding whether they are due to undergo punishments. Although perceived as censorious, the deservingness of the subject is not a factor in their imposition.

How about the possibility of cases in which the state can legitimately aim at responding to people's deservingness? Can these be legitimate? And if so, in particular, can there be preventive orders that aim at responding to people's deservingness? These might legitimately exist only in a thin sense of 'desert,' in the manner of the negative retributivist, using the wrongdoing as a tripwire that creates liability to preventive measures. A harder case would be to show where the state can legitimately respond directly and in proportion to the degree of a person's moral deservingness, using preventive orders. However, it is controversial that even paradigmatic cases of punishment should do that.

A proper assessment of measures like civil preventive orders should take into account all of the ethical benefits and burdens at stake. These will include: harm prevented (including, the value of a less harmful environment, with more certainty and less criminality); the rights infringed upon by preventive measures; distributive concerns; harms and deprivations to the bearer of the order, in the form both of libertyrestrictions and stigmatisation (in comparison to the harms that might be imposed by alternatives). It is satisfying to attain the combination of theoretical consistency and practical directiveness that is characteristic of the positions that I have criticised in this paper. In their place, I can only offer a measure of complexity and a plea for a research paradigm that encompasses censorious state hard treatment in general, rather than a mere subset of that category. The danger remains, in making this shift, that we wind up legitimating what look like oppressive policies in which significant sentences are passed with diminished procedures. However, a benefit-aside from greater conceptual coherence-is that we turn attention to a broader set of state practices.

That we have reached the questions I have asked might tempt the reader to wonder if the argument has achieved only a kind of semantic vandalism: what was clear before has now become unclear, and there has not been a manifest accompanying gain. What do we achieve by making the shift that I am urging? The move achieves more than an idiosyncratic renaming of our practices, since it forces our focus onto the substantive reasons we have for withholding some coercive state acts until we have a high standard of evidence for their justification, instead of merely falling back on the name 'punishment.' A semantic shift that is both on reflection more coherent, and that forces us to consider more closely our reasons, is a form of progress.

\footnotetext{
${ }^{70}$ For discussion of such cases in different terms, see Walen, "A Unified Theory of Detention, With Application to Preventive Detention for Suspected Terrorists".
} 
Acknowledgements For valuable input I am grateful to the journal's anonymous referees, as well as Kimberley Brownlee, Kat Hadjimatheou, Emily McTernan, Tom Sorell, and Alec Walen.

Funding Funding was provided by Economic and Social Research Council ES/K000098/1.

Open Access This article is licensed under a Creative Commons Attribution 4.0 International License, which permits use, sharing, adaptation, distribution and reproduction in any medium or format, as long as you give appropriate credit to the original author(s) and the source, provide a link to the Creative Commons licence, and indicate if changes were made. The images or other third party material in this article are included in the article's Creative Commons licence, unless indicated otherwise in a credit line to the material. If material is not included in the article's Creative Commons licence and your intended use is not permitted by statutory regulation or exceeds the permitted use, you will need to obtain permission directly from the copyright holder. To view a copy of this licence, visit http://creativecommons.org/licen ses/by/4.0/.

Publisher's Note Springer Nature remains neutral with regard to jurisdictional claims in published maps and institutional affiliations. 